\title{
Special Issue: Nitrogen Transport and Assimilation in Plants
}

\author{
Bertrand Hirel * and Anne Krapp \\ Institut Jean-Pierre Bourgin, Institut National de la Recherche Agronomique (INRA), Centre de \\ Versailles-Grignon, Unité Mixte de Recherche 1318 INRA-Agro-ParisTech, Equipe de Recherche Labellisée, \\ Centre National de la Recherche Scientifique (CNRS) 3559, RD10, Versailles Cedex F-78026, France; \\ anne.krapp@versailles.inra.fr \\ * Correspondence: hirel@versailles.inra.fr; Tel.: +33-1-30-83-30-89 \\ Academic Editor: Peter Langridge \\ Received: 25 August 2016; Accepted: 25 August 2016; Published: 29 August 2016
}

\section{Introduction}

The doubling of the world's agricultural production for the past four decades has been associated with a seven-fold increase in nitrogen $(\mathrm{N})$ fertilization [1] which has caused major detrimental impacts on the diversity and functioning of the non-agricultural bacterial, animal and plant ecosystems, notably through the process of freshwater and marine ecosystem eutrophication [2]. In addition there can be gaseous emissions of nitrogen oxides reacting with the stratospheric ozone and the emissions of toxic ammonia into the atmosphere.

Between now and 2050, the human population is expected to increase from 7.5 to 9.7 billion people. Therefore, the challenge for the next decades will be to accommodate the needs of the expanding world's population by developing a highly productive agriculture, while at the same time preserving the quality of the environment. Furthermore, farmers are facing increasing economic pressure with the rising cost of fossil fuels required for producing $\mathrm{N}$ fertilizers.

It is therefore crucial to improve our knowledge on the critical steps controlling $\mathrm{N}$ use efficiency (NUE), which can be defined as the yield per unit of available mineral nutrients in the soil (including the residual mineral nutrients present in the soil and those provided by fertilization). Mineral use efficiency is composed of two components: uptake efficiency (NupE, which is the ability of plants to take up $\mathrm{N}$ from the soil such as nitrate or ammonium), and utilization efficiency (NutE, which is the ability of plants to use and remobilize the $\mathrm{N}$ to produce biomass and grains in particular).

Differences between and within plant species in their ability to grow and yield well when $\mathrm{N}$ availability is high or low depends on both NupE and NutE. In the plant kingdom, considerable inter- and intra-specific variability exists for these two physiological traits, but the identification of plant characteristics and underlying genes and metabolic pathways that are involved in the control and efficiency of NupE and NutE is complex because it results from a combination of direct and indirect effects both at the genetic and physiological levels [3]. Therefore, combining genetic and molecular physiology both on model and crop plants is one of the best ways to properly investigate the various biological processes governing acquisition and utilization of $\mathrm{N}$ for further genetic improvement.

Although it will be necessary to increase agricultural production by 1.7 -fold by 2050 to feed the growing world's population, the detrimental impact of the overuse of $\mathrm{N}$ fertilizers on the environment can also be minimized if it is accompanied by sustainable agricultural practices, such as the rationalization of fertilizer usage and the development of alternative agricultural practices. Such alternative practices are often based on the use of plants (as a main crop or as cover crops) that are able to develop atmospheric $\mathrm{N}\left(\mathrm{N}_{2}\right)$ fixing and arbuscular mycorrhizal fungi (AMF) symbiotic associations to significantly reduce $\mathrm{N}$ fertilizer usage [4]. 


\section{Special Issue Overview}

Following the invitation of the Editor-in-Chief Peter Langridge, six articles have been published in a Special Issue of Agronomy entitled "Nitrogen Transport and Assimilation in Plants". These articles cover a wide variety of research areas related to nitrogen $(\mathrm{N})$ nutrition, including $\mathrm{N}$ transport, assimilation and recycling, $\mathrm{N}$ economy and $\mathrm{N}$ environmental interactions.

It is intended that these articles will provide either an overview of the latest information on the subject of $\mathrm{N}$ assimilation in plants, or a critical discussion of a particular research area. Two review articles [5,6] contain extensive overviews of [4] $\mathrm{N}$ assimilation and management, as a function of various environmental cues in conifers and [5] the colonization of plants by AMF. A detailed characterization of two key nitrate transporters in the alga Chlamydomonas reinhardtii (P.A. Dang) [7] and of the role of a gene encoding asparagine synthetase in Arabidopsis thaliana (L.) Heynh. [8], another model species, are included in two of the four research articles. The importance of $\mathrm{N}$ remobilization and recycling in two crops, namely Hordeum vulgare L. and oilseed rape (Brassica napus L.), is presented in the two other research papers, with particular emphasis on the role of senescence and autophagy $[9,10]$.

The help and guidance of the staff of the editorial office, in particular Sally Cheng and Yanping Mou, are gratefully acknowledged.

\section{Conclusions}

This Special Issue contains different papers presenting overviews and new results on different aspects of $\mathrm{N}$ uptake and utilization in model and crop species. These papers cover a variety of biological processes related to $\mathrm{N}$ utilization, including nitrate transport, amino acid biosynthesis, and $\mathrm{N}$ remobilization and management, notably during senescence and when the plants develop a symbiotic association with AMF.

We hope that this Special Issue will stimulate research in the field of $\mathrm{N}$ uptake and assimilation not only for knowledge improvement but also for fostering future agronomic applications.

Author Contributions: Both the authors equally contributed to the design and drafting of this paper.

Conflicts of Interest: The authors declare no conflict of interest.

\section{Abbreviations}

The following abbreviations are used in this manuscript

$\begin{array}{ll}\text { AMF } & \text { Arbuscular Mycorrhizal Fungi } \\ \mathrm{N} & \text { Nitrogen } \\ \mathrm{N}_{2} & \text { Atmospheric Dinitrogen } \\ \mathrm{NUE} & \text { Nitrogen Use Efficiency }\end{array}$

\section{References}

1. Galloway, J.N.; Townsend, A.R.; Erisman, J.W.; Bekunda, M.; Cai, Z.; Freney, J.R.; Martinelli, L.A.; Seitzinger, S.P.; Sutton, M.A. Transformation of the nitrogen cycle: Recent trends, questions, and potential solutions. Science 2008, 320, 889-892. [CrossRef] [PubMed]

2. London, J.G. Nitrogen study fertilizes fears of pollution. Nature 2005, 433, 791.

3. Hirel, B.; Le Gouis, J.; Ney, B.; Gallais, A. The challenge of improving nitrogen use efficiency in crop plants: Towards a more central role for genetic variability and quantitative genetics within integrated approaches. J. Exp. Bot. 2007, 58, 2369-2387. [CrossRef] [PubMed]

4. Hirel, B.; Tétu, T.; Lea, P.J.; Dubois, F. Improving nitrogen use efficiency in cops for a sustainable agriculture. Sustainability 2011, 3, 1452-1485. [CrossRef]

5. Bücking, H.; Kafle, A. Role of arbuscular mycorrhizal fungi in the nitrogen uptake of plants: Current knowledge and research gaps. Agronomy 2015, 5, 587-612. [CrossRef]

6. Cañas, R.A.; de la Torre, F.; Pascual, M.B.; Avila, C.; Cánovas, F.M. Nitrogen economy and nitrogen environmental interactions in conifers. Agronomy 2016, 6, 26. [CrossRef] 
7. Higuera, J.J.; Calatrava, V.; González, Z.; Mariscal, V.; Siverio, J.M.; Fernández, E.; Galván, A. NRT2.4 and NRT2.5 are two half-size transporters from the chlamydomonas NRT2 family. Agronomy 2016, 6, 20. [CrossRef]

8. Gaufichon, L.; Marmagne, A.; Yoneyama, T.; Hase, T.; Clément, G.; Trassaert, M.; Xu, X.; Shakibaei, M.; Najihi, A.; Suzuki, A. Impact of the disruption of ASN3-encoding asparagine synthetase on arabidopsis development. Agronomy 2016, 6, 12. [CrossRef]

9. Koeslin-Findeklee, F.; Horst, W.J. Contribution of nitrogen uptake and retranslocation during reproductive growth to the nitrogen efficiency of winter oilseed-rape cultivars (Brassica napus L.) differing in leaf senescence. Agronomy 2016, 6, 1. [CrossRef]

10. Avila-Ospina, L.; Marmagne, A.; Soulay, F.; Masclaux-Daubresse, C. Identification of barley (Hordeum vulgare L.) autophagy genes and their expression levels during leaf senescence, chronic nitrogen limitation and in response to dark exposure. Agronomy 2016, 6, 15. [CrossRef]

(C) 2016 by the authors; licensee MDPI, Basel, Switzerland. This article is an open access article distributed under the terms and conditions of the Creative Commons Attribution (CC-BY) license (http://creativecommons.org/licenses/by/4.0/). 